УДК 2:159.922:316.613

Н. А. Ємець, к. фрілос. н., доцент, К. О. Спас, магістрант

\title{
РЕЛІГІЙНА СОЦІАЛІЗАЦІЯ ОСОБИСТОСТІ У СУЧАСНОМУ СОЦІОКУЛЬТУРНОМУ ПРОСТОРІ
}

Анотація. У статті розглядаються проблеми релігійної соціалізації, їі роль у духовнокультурному становленні особистості у сучасному культурному просторі. Автор детально аналізує моделі релігійної соціалізації особистості у вітчизняній та західній науці, досліджує основні механізми (агенти) соціалізації, а також шляхи їх прямого та опосередкованого впливу на особистість та формування їі релігійних уявлень. Велика увага приділена аналізу впливу релігійних організацій на процес релігійної соціалізації особистості.

Ключові слова: релігійність; релігійна соціалізація; агенти соціалізації; моделі релігійної соціалізації; релігійні організації.

Н. А. Емець, к. филос. н., доцент,

Е. А. Спас, магистрант

\section{РЕЛИГИОЗНАЯ СОЦИАЛИЗАЦИИ ЛИЧНОСТИ В СОВРЕМЕННОМ СОЦИОКУЛЬТУРНОМ ПРОСТРАНСТВЕ}

Аннотация. В статье рассматриваются проблемы религиозной социализации, ее роль в духовно-культурном становлении личности в современном культурном мире. Автор подробно анализирует модели религиозной социализации личности в отечественной и западной науке, исследует основные механизмы (агенты) социализации, а также пути их прямого и опосредованного воздействия на личность и фрормирования ее религиозных представлений. Большое внимание уделено анализу влияния религиозных организаций на процесс религиозной социализации личности.

Ключевые слова: религиозность; религиозная социализация; агенты социализации; модели религиозной социализации; религиозные организации.

N. A. Yemets, Candidate of Philosophical Sciences, Associate Professor,

K. O. Spas, Master Student

\section{RELIGIOUS SOCIALIZATION OF PERSONALITY INMODERN SOCIOCULTURAL SPACE}

Urgency of the research. The question why people come to believe, feel, and behave religiously is one of the most discussing one in the scientific discourse.

Target setting. Of particular interest is not only why people are religious, but why they are religious in the way they are. A new focus in the research, therefore, is the process of religious socialization.

Actual scientific researches and issues analysis. L. Kondratik, E. Duluman, V. Dokash, $N$. Pivoparova and others study the phenomenon of religiosity, such well-known researchers as V. Bezrogov, L. Ipatov, Golovach, K. Litvishko and others analyze mechanisms and models of religious socialization.

Uninvestigated parts of general matters defining. There are no studies devoted to the process of religious socialization of personality in modern cultural space.

The research objective. The purpose of the article is to study the features of religious socialization of personality in modern cultural space.

The statement of basic materials. The religious socialization is a process by which society passes the system of its religious orientation, knowledge, and instructions from generation to generation. The process of religious socialization orientates the person to the familiarization and assimilation of universally accepted religious principles, principles and norms acquired by humanity, and those principles which are canonical in the system of functioning of one or another type of religion. The process of religious socialization is determined by the family, peers and the religion organizations.

Conclusions. Analysis of the process of religious socialization shows that religion has and continues to impact almost every aspect of human life. Religion affects the individual through mechanisms 
and agents of religious socialization, and the individual perceives and reflects these influences in connection with its specific features.

Keywords: religiosity; religious socialization; agents of socialization; models of religious socialization; religious organizations.

$$
\text { DOI 10.25140/2412-1185-2017-2(10)-29-33 }
$$

Актуальність теми дослідження. Релігія як соціальний інститут є системою соціальних норм за допомогою яких формується, спрямовується соціальна діяльність людей. Релігійність визначається критерієм релігії і за своєю суттю є проявом суб'єкта (людство, нація, колектив, група, індивід), явищем суспільним за сутністю, походженням, функціональністю і водночас явищем глибоко інтимним, на відміну від релігії, яка має об'єктивний характер. Особливо гостро це співвідношення проявляється в процесі соціалізації особистості, який сприяє включенню індивіда до системи соціальних зв'язків та відносин, його активної взаємодії з середовищем існування, в результаті якої людина засвоює зразки поведінки, соціальні норми і цінності, необхідні для її успішної життєдіяльності у даному суспільстві. Релігійна соціалізація є складовим компонентом загальної соціалізації, тому дослідження цього феномену дає змогу зрозуміти основні шляхи становлення творчо-активної особистості.

Постановка проблеми. У вітчизняному науковому дискурсі все більшу увагу приділяють дослідженню процесів залучення наших сучасників до історії і культури релігії, способу життя віруючих людей. Прояв і зміна ступеня релігійності вивчається як в житті окремої особистості, так і в якості особливої характеристики суспільної свідомості. Дослідження проводяться в рамках психології, педагогіки, соціології, політології.

Феномен релігійності досліджується в тісному зв'язку з такими поняттями, як етнорелігійна ідентичність, конфесійна самосвідомість, i, насамперед, релігійна соціалізація. В залежності від предмета дослідження кожна наука використовує свої методи вивчення та опису феномену релігійності і пов'язані з ним явища особистісного і суспільного розвитку. В контексті гуманітарних дисциплін, релігійність досліджується насамперед на індивідуальному рівні, як певна індивідуальна характеристика, що формує особливий склад особистості, обумовлює її поведінку, образ думок тощо. Але цей вплив не безумовний i, перш за все, не обумовлений самою природою людини, iї біологічними характеристиками. Він можливий виключно в рамках соціуму, існує в ньому, постійно відтворюється та поширюється.

Аналіз останніх досліджень і публікацій. Аналіз феномену релігійності представлений у науковому доробку Л. Кондратик, Є. Дулуман, В. Докаш, Н. Пивопарової та ін. Дослідженням механізмів та моделей релігійної соціалізації займаються такі відомі дослідники як: В. Безрогов, Л. Іпатова, В. Чеснокова, Т. Склярова, Н. Головач, К. Літвішко та ін. Загалом, увага дослідників зосереджена на механізмах, за допомогою яких релігійні уявлення передаються у суспільстві.

Виділення недосліджених частин загальної проблеми. Незважаючи на поширення даної проблематики у наукових розвідках сучасних авторів, проблема релігійної соціалізації особистості розглядається лише в контексті дослідження цих механізмів «трансляції», окремо ж соціокультурний дискурс релігійної соціалізації особистості фактично залишається не дослідженим.

Постановка завдання. Розглядається процес релігійної соціалізації у контексті духовнокультурного становленні особистості в сучасному культурному просторі.

Виклад основного матеріалу дослідження. Для розгляду особливостей релігійної соціалізації особистості у сучасному культурному просторі, на нашу думку, варто дослідити змістовне наповнення поняття «релігійність».

Відзначимо, що тлумачення поняття «релігійність» залежить від того, на яких аспектах (особистісних чи соціальних) зосереджуються дослідники при вивченні релігійного феномену. Одні дослідники терміном «релігійність» позначають певну індивідуальну чи колективну якість, що $€$ конкретним проявом релігії в індивідуальній або колективній свідомості. Інші - вбачають в релігійності певний душевний, психічний стан окремих індивідів, груп чи спільнот, характерною ознакою яких є віра в надприродне і відправляння релігійного культу.

Релігійність визначається критерієм релігії і за своєю суттю є проявом суб'єкта (людство, нація, колектив, група, індивід), явищем суспільним за сутністю, походженням, функціональністю і водночас явищем глибоко інтимним, на відміну від релігії, яка має об'єктивний характер. 
У «Філософському словнику» наводяться три значення терміну «релігійність»: 1) перебільшена, невідповідна заглибленість людини в релігійну проблематику»; 2) можливість для людини вступати у взаємини з Богом; 3) людське прагнення діяти за межами чисто тілесних інтересів, брати участь у культурі та спільності духовно настроєних людей [1, с. 345].

В українському релігієзнавчому словнику релігійність пояснюється як поняття, що характеризує якісну та кількісну визначеність (ступінь, рівень, характер) суб'єктивного засвоєння релігійних ідей, цінностей, норм та їх вплив на поведінку, життєдіяльність віруючих, релігійної спільноти; як ціннісно-життєва орієнтація, суб'єктивна якість свідомості індивіда, його внутрішня здатність до реалізації релігійних установок [2, с. 112].

Згідно із сучасними вітчизняними релігієзнавчими тлумаченнями, релігійність, передусім, $\epsilon$ конкретизацією зв'язку з трансцендентним, надприродним, вона «має психічну сутність і реалізується в свідомості індивідів, але водночас виходить своїм змістом за межі індивідуальної свідомості». У такий спосіб релігійність «поєднує внутрішньо-психічний і зовнішньо-символічний вияв релігії».

Формування релігійності на індивідуальному рівні відбувається під час процесу релігійної соціалізації особистості. Релігійна соціалізація - це процес, за допомогою якого суспільство передає від покоління до покоління систему релігійної орієнтації, знань, настановлень, набутих за період життєтворчості індивіда, нації, людства. Релігійна соціалізація тісно пов'язана з виробленням такого поняття, як «релігієзнавча культура», оскільки саме вона орієнтує особистість на ознайомлення і засвоєння загальновизнаних релігійних засад, принципів і норм, набутих людством, і тих принципів, які є канонічними в системі функціонування того чи іншого типу релігії.

В руслі соціологічного підходу релігійна соціалізація особистості $є$ акумулюванням індивідом норм і цінностей тієї релігії, до якої вона належить (Г. Тард), научіння (Т. Шибутіані), входження в релігійне середовище, пристосування до нього (Б. Паригін), всотування спільних релігійних цінностей у процесі спілкування зі значними іншими (Т. Парсонс).

Як вважають дослідники, у людини стільки «соціальних Я», скільки існує осіб і груп, думка яких для неї важлива. Тому й процес соціалізації різноманітний та не завжди непередбачуваний. Значний внесок у вирішення проблем соціалізації взагалі та релігійної соціалізації, зокрема, вніс 3. Фрейд своїм вченням про несвідоме. Вчений наголошував на особливій важливості дитячого і юнацького віку, коли визначається становлення світоглядних засад особистості (зокрема й сприйняття релігійних канонів) та подальша релігійна соціалізація. Відповідно до теорії 3. Фрейда, у процесі соціалізації базовими є психосексуальні стадії розвитку, в яких «розгортаються» вроджені властивості індивіда. Релігія, на думку психоаналітика, є певним механізмом контролю над інстинктами і тому має культивуватися родиною. А. Фрейд же наголошує, що релігійна соціалізація впливає на формування свідомості та самосвідомості, зобов'язань перед суспільством, сім'єю, близькими, самим собою [3, с. 111].

У науковій літературі виділяють декілька моделей релігійної соціалізації.

Перша модель релігійної соціалізації активно розглядалася в радянському науковому дискурсі. В контексті зазначеної моделі, релігійна соціалізація - це спосіб трансляції та відтворення релігії. «В основному існує три канали відтворення релігії: перший - виховання в сім'ї віруючих; другий - місіонерська діяльність проповідників релігії; третій - вплив різних індивідуальнопсихологічних елементів» [4, с. 52]. Агентом релігійної соціалізації визначалось виховання у сім’ї віруючих (В. Павлюк, Ю. Борунков, Є. Дулуман). На нашу думку, другий та третій шляхи, або ж агенти навернення в цій схемі нерозривно пов'язані. Прийняття проповіді без нагального духовного запиту, що походить від самої людини, не можливе за умов ії комфортного фрізичного та психологічного існування. Модель передачі, розглядає батьків як домінантних активних агентів соціалізації, які формують релігійну належність своїх дітей. В цій моделі діти виступають як пасивні об'єкти соціалізації, а кореляція релігійних вірувань і практик між батьківським і дитячим поколіннями розглядається як показник успішності релігійної соціалізації. Основні досліджувані показники в рамках даної моделі - це відвідування родиною церкви, важливість релігії в сімейному житті, віра у існування та всемогутність Бога, частота молитов. Результати емпіричних досліджень довели, що релігійна поведінка батьків успадковується і їхніми дітьми. Так, відвідування батьками церкви асоціюється з участю дітей у церковному житті (Б. Сузеєделіс), а батьківські релігійні практики позитивно впливають на всі прояви релігійності у підлітковому віці (П. Озорак). Проте, ця модель не пояснює, яким саме чином відбувається передача релігійних 
вірувань. Пізніше до цієї моделі була включена теорія научіння, яка давала змогу пояснити релігійну соціалізацію як моделювання дитиною батьківських релігійних практик. Так, Е. Оман стверджує, що моделювання виступає ключовим аспектом у передачі релігійних цінностей від батьків до дітей. Вчений в своїх дослідженнях передачі релігійних цінностей спирається на теорію А. Бандури, який зауважує, що навчити чомусь важко, батькам значно легше для дитячого розуміння показати це на власному прикладі. Тобто діти вже не розглядаються як пасивні об'єкти соціалізації, а як суб'єкти, які, спостерігаючи за релігійними практиками батьків, виробляють власну модель релігійної поведінки [4, с. 53].

Друга модель релігійної соціалізації - це модель угоди (або ж транзакції). В контексті цієї моделі стверджується, що діти не знаходяться під одностороннім впливом своїх батьків, а взаємно впливають на них (О. Кучінські). Модель релігійної соціалізації як угоди розглядає дітей як активних суб'єктів, і припускає, що батьківська родина створює певне середовище, в якому діти вибудовують власні релігійні погляди (К. Волкер).

Третя модель - каналювання, або ж трансформації, об'єднує дві попередні моделі релігійної соціалізації і поширює перелік активних агентів соціалізації за рамки родини (наприклад, на однолітків, колег та релігійних лідерів). Ця гіпотеза припускає, що батьки формують релігійні норми та уявлення своїх дітей безпосередньо в дитинстві; в той же час, батьки стають причиною входження дітей до релігійних спільнот та громад, де ті мають змогу спілкуватися з релігійними однолітками і наставниками. В даному випадку безпосередній вплив на соціалізацію чинять саме позасімейні агенти, в той час як батьківська соціалізація продовжує впливати на дітей опосередковано. Вперше цю модель сформулював та дослідив Г. Хіммельфарб, який досліджував каналювання релігійних уявлень серед американських євреїв. Він виявив, що серед єврейського населення США основним фактором формування релігійності та релігійних практик виступає релігійна належність одного з подружжя, в той час як батьківський соціалізуючий вплив виражається лише опосередковано (батьки стають причиною входження в групу, де їх дитина з часом знаходить собі чоловіка/дружину) [4, с. 54].

На соціалізуючому впливі релігійних організацій наголошує і Н. Головач. Вчений зазначає, що соціалізація в релігійних організаціях здійснюється під впливом практично всіх механізмів соціалізації [5, с. 22]. Проте в залежності від конфесії, до якої належить та або інша організація, роль механізмів та їх співвідношення різні. Так, в парафріях православної церкви провідними механізмами можна вважати традиційний і інституційний. У ряді сектантських організацій - інституційний та стилізований, а в організаціях ряду східних конфесій - інституційний та рефлексивний.

У процесі соціалізації, зазначає Н. Головач,релігійні організації реалізують ряд функцій:

- ціннісно-орієнтаційна функція релігійних організацій проявляється в тому, що вони прагнуть сорормувати певну систему вірувань, позитивне ставлення до релігійних цінностей і норм. Це здійснюється як у процесі культових дій, так і в різних формах релігійної освіти;

- регулятивна функція проявляється в тому, що релігійні організації культивують серед своїх членів поведінку, відповідну релігійним нормам. Це здійснюється в процесі колективних культових дій і всієї життєдіяльності організацій;

- комунікативна функція реалізується у створенні умов для спілкування віруючих, у певних формах її організації, а також у культивуванні норм спілкування, відповідних віроповчальним принципам конкретної релігії;

- милосердна функція релігійних організацій реалізується в різноманітних сферах діяльності через милосердя та благодійність як в рамках самих організацій, так і за їх межами, завдяки чому члени організації набувають певний досвід;

- компенсаторна фрункція проявляється в гармонізації духовного світу віруючих;

- виховна функція - релігійне виховання людини [5, с. 54].

Процес релігійної соціалізації особистості в контексті нашої православної традиції має дві фрази: пасивну та активну. Пасивна фраза триває з моменту хрещення людини (формального зміни релігійного статусу) появи інтересу до православного віровчення і богослужіння, потім настає активна фаза воцерковлення, яка завершується здобуттям особистістю місця в церковному просторі (сутнісної зміни релігійного статусу).

Сучасні особливості освоєння православної традиції детально висвітлені в роботах Л. Іпатової, В. Чеснокова. Так, Л. Іпатова характеризує типи релігійного навернення у православній традиції і виділяє групи православних за самоідентифікаціїєю [6, с. 23]. Найбільш поширена 
група - це ті особистості, для яких «принципово важливо не стільки жити «по-християнськиі», скільки народитися і померти», тобто це ті з наших співгромадян, хто звертається до церкви лише з приводу хрещення та відспівування. Дослідниця виділяє і категорію православних, які відрізняються специфічною самостійністю в православній соціалізації. Їм властива незалежність суджень про релігійне життя, недовіра до служителів культу, незалежність від церковних авторитетів; прагнення до духовного комфорту - спроба у зручній для собі фрормі поєднати інформацію про духовний світ. Ті особистості, які реально соціалізовані у православній культурі, на думку Л. Іпатової, приймають існуючі в церкві норми і зразки поведінки, орієнтуючись на тих, хто належить до цієї традиції. В першу чергу такого роду орієнтири - це священики як легітимні носії цієї культури і традиції, в другу чергу - знайомі віруючі «зі стажем церковного життя». Автор дослідження звертає увагу на істотну особливість соціалізації в православ'ї - православна ідентичність особистості конструюється і сприймається з боку іншої людини.

На думку В. Чеснокової, входження в релігійну традицію, освоєння віровчення, правил і норм поведінки в значній мірі визначається особливостями релігійної культури [7, с. 30]. Кожна релігійна культура передбачає інтелектуальне освоєння її спадщини, має певний спектр обмежень поведінки, а також правила регулювання емоційної сфери своїх послідовників. Освоєння ж людиною релігійної традиції православ'я, зобов'язує її бути люблячою, доброю, милостивою.

Висновки. Таким чином, релігійна соціалізація являє собою складний і неоднозначний процес, в основі якого лежить розуміння релігії, як своєрідної духовно-моральної опори суспільства, за допомогою якої зберігалися й передавалися від покоління до покоління моральні норми і принципи, традиції, звичаї і обряди, національні святині. Релігія давала і продовжує давати відповіді на одвічні питання внутрішнього стану людини. Вона є формою безпеки для особистості, чого не може зробити жодна світська інституція. Релігія та особистість - це особливі соціальні сутності, взаємозумовлювані та взаємодоповнювані. Так, перша впливає на другу через механізми й агентів релігійної соціалізації, а друга вибірково сприймає та осмислює зазначені впливи у зв'язку з конкретними своїми рисами. Реальним же посередником між ними обома виступає релігійний дискурс (з боку церкви - це, наприклад, проповідь, з боку людини - молитва) як цілісний та динамічний соціально-комунікативний простір висловлювань на відповідну тематику.

\section{Література}

1. Філософський словник / за ред. В.І. Шинкарука. - 2-е вид., перероб. і доп. - К. : Голов. ред. УРЕ, 1986. - С. 345.

2. Релігієзнавчий словник / за ред. А. Колодного і Б. Лобовика. - К., 1996. - С. 112.

3. Фрейд 3. Будущее одной иллюзии / 3. Фрейд // Психоанализ. Религия. Культура. - М. : Прогресс, 1991. - 406 с.

4. Літвішко, К. В. Моделі релігійної соціалізації: досвід Заходу / К. В. Літвішко // Філософія і філологія - Релігієзнавство. Національний Університет біоресурсів і природокористування України. - 2014. - Вип. 3. - С. 51-55.

5. Головач, Н. М. Релігійна соціалізація особистості у сучасному культурному просторі / Н. М.Головач // Міжнародний вісник: Культурологія. Філологія. Музикознавство. - 2016. - Вип. 1. - С. 21-25.

6. Ипатова, Л.П.Современные особенности освоения православной традиции / Л. П. Ипатова // Традиции и инновации в современной России. Социологическийанализвзаимодействия и динамики. - М., 2008. - 543 с.

7. Чеснокова, В. Ф. Тесным путем: процесс воцерковления населения России в конце XX века / В. Ф. Чеснокова. М. : Академический проект, 2005. - 345 с.

\section{References}

1. Shynkaruk, V. I. (Ed.). (1986). Filosofskyi slovnyk [Dictionary of Philosophy]. Kyiv [in Ukrainian]

2. Kolodnyi, A., Lobovyk, B. (1996). Relihiyeznavchyy slovnyk [Dictionary of Religions]. Kyiv [in Ukrainian].

3. Freyd, Z. (1991). Budushchee odnoy yllyuzyy. Psykhoanalyz. Relyhyya. Kultura. [The Future of an Illusion. Psychoanalysis. Religious. Culture]. Moscow [in Russian].

4. Litvishko, K. V. (2014). Modeli relihiynoyi sotsializatsiyi: dosvid Zakhodu [Models of religious socialization: the experience of the West]. Filosofiya i filolohiya. Seria Relihiyeznavstvo. - Philosophy and philology. Religious studies, 3, 51-55 [in Ukrainian].

5. Holovach, N. M. (2016). Relihiyna sotsializatsiya osobystosti u suchasnomu kulturnomu prostori [Religious socialization in contemporary cultural space]. Mizhnarodnyy visnyk: Kulturolohiya. Filolohiya. Muzykoznavstvo - International Journal of Culturology. Philology. Musicology, 1, 21-25 [in Ukrainian].

6. Ipatova, L. P. (2008). Sovremennye osobennosti osvoeniia pravoslavnoi traditsii [Modern features of the development of the Orthodox tradition]. Traditsii $i$ innovatsii v sovremennoi Rossii Sotsiologicheskiianalizvzaimodeistviia i dinamiki - Traditions and innovations in modern Russia. Sociological analysis of interaction and dynamics. Moscow [in Russian].

7. Chesnokova, V. F. (2005). Tesnym putem: protsess votserkovlenyya naselenyya Rossyy $v$ kontse XX veka [In a close way: the process of the churching of the population of Russia at the end of the 20th century]. Moscow [in Russian].

Бібліографічний опис для цитування:

Надійшла 21.10.2017

Ємець, Н. А. Релігійна соціалізація особистості у сучасному соціокультурному просторі / Н. А. Ємець, К. О. Спас // Проблеми соціальної роботи: фрілософія, психологія, соціологія. - 2017.- № 2 (10). - С. 29-33. 